\title{
An Analysis of Reading Comprehension Questions in English Textbooks for SMAN Kota Padang: HOTS
}

\author{
Yetti Zainil $^{1}$, Rusdi Noor Rosa ${ }^{2}$, Fitrawati $^{3}$ \\ ${ }^{1}$ Universitas Negeri Padang, Padang, Indonesia, $\triangle$ (e-mail) yettizainil@fbs.uno.ac.id \\ ${ }^{2}$ Universitas Negeri Padang, Padang, Indonesia, $\square$ (e-mail) rusdinoorrosa@fbs.unp.ac.id \\ ${ }^{3}$ Universitas Negeri Padang, Padang, Indonesia, $\$ (e-mail)Fitra_sasing@yahoo.com
}

\begin{abstract}
This paper presents the investigation on the reading comprehension questions found in the textbooks for Senior High School EFL classrooms in Padang, West Sumatra related to the level of the reading comprehension questions. A basic premise is that higher-order thinking skill has become a major theme in education, however, to what extent EFL teachers have applied it, does not clearly defined yet. This study was carried out in EFL classrooms in four senior high schools in Padang, West Sumatra, Indonesia aimed at identifying the level of reading comprehension questions. All reading comprehension questions found in the English textbooks used by the students at all grades at public senior high school were analyzed using Higher Order Thinking Skill category. Ten textbooks were identified used by the English teachers in SMA Negeri Kota Padang. The findings show that the level of the reading comprehension questions found in those textbooks were mostly in the lower level (LOTS). Some of the questions found in the textbooks have already in HOTS category, however, the number was still far below LOTS questions. Therefore, it is suggested that teachers need to use other sources besides textbook analysed in this research to provide students with higher-order questions in order to encourage the student to have critical thinking.
\end{abstract}

Keywords: Reading comprehension questions, Higher Order Thinking Skills, Stimulated recall interview.

\section{INTRODUCTION}

Higher-order thinking skills have become a major theme in education (Vijayaratnam in Damanik \& Zainil, 2019). One of the ways to improve students' higher-order thinking skills (HOTS) is by implementing it in the teaching-learning process. In implementing HOTS in the learning process, teachers are instructed to provide some direct HOTS questions for learners or they can choose some assignment or activities from textbooks that provide HOTS questions.

According to Graves (2000), a textbook is one os the sources of information to be used in the process of teaching and learning. Moreover, a textbook may help an educator in creating questions at HOTS level to develop students' thinking. Using textbooks in teaching has both benefits and detriments, depends on the way the textbooks are used and what the contexts are.

The advantages are textbooks may provide a group of visuals, activities, readings, and saves the time of the teacher in discovering or deepen the materials. However, many critics pop out about textbook usage in educational matters. According to Pratiwi (2014), some of those critics claim that the textbook contains too little material and it is not sufficiently challenging for the teachers and the students. Therefore, the textbook needs to be evaluated and analyzed by the teachers before it is given to the students.

Cunningsworth in Febrina, Usman, \& Muslem (2019) stated that "No coursebook designed for the general market will be absolutely ideal for your particular group of learners..." Consequently, teachers have to confirm and evaluate if or not the content of the textbook is appropriate with the instructional objective, the students' level, and the students' needs before the textbook itself is applied by the students and the teachers during the process of teaching and learning in the classroom.

There are some elements of the textbook which need evaluations, such as the layouts of the textbook, the exercises, the instructions in the textbook, and the teaching material. The quality of those aspects could influence the students' outcomes and the students' motivation in the learning process. One of the elements of the textbook that needs evaluation is the exercises or the tasks.

Ur in Pratiwi (2014) claims that the textbook has to provide varied topics and tasks for different learners' levels, learning styles, and interests. A textbook has to demonstrate assignments and activities for both educators and learners. Thus, the teachers need to check the existence of varied tasks or exercises in the textbook. 
Some researchers have researched reading exercise based on HOTS, Pratiwi (2014) with the title "An Analysis of Reading Exercises in Pathway to English Textbook for the Eleventh Grade of Senior High School Students". This study aimed to get the practical proof of the distribution of the higher-order thinking skill based on an updated edition of Bloom's Taxonomy in the essay question of the reading tasks in Pathway to English textbook which is used for the students at the $11^{\text {th }}$ grade of Senior High School.

Febrina, Usman, \& Muslem (2019) investigated the three levels of the cognitive aspect of edited Bloom's Taxonomy used in the textbook with title Bahasa Inggris SMA/MA/SMK/MAK grade 11th semester 1: analyzing level (C4), evaluating level (C5), and creating level (C6). Damanik (2019) analyzed English textbooks based on HOTS at one of SMA Negeri in Padang. Her study revealed that the questions of reading comprehension were in all levels of cognitive level proposed by Bloom (1956) and Anderson \& Krathwohl (2001); but, the LOTS questions outraged the HOTS questions.

However, those studies mentioned above investigated the textbooks partially not comprehensively. This research tries to analyze questions found in textbooks used in English classes at SMAN Padang. In order to guide this study, the subsequent research question was addressed:

"What are the levels of questions about reading comprehension found in the English textbooks used by the SMAN Kota Padang?"

\section{LITERATURE REVIEW}

The application of textbookss in education has both benefits and detriments, depending on how the textbooks are utilized and the context for their use. Richards in Damanik (2019) mentioned some advantages of the textbook, they are:

a. Providing structure and a syllabus for a program.

b. Helping standardize the instruction.

c. Maintaining quality.

d. Providing a variety of learning resources.

e. They are efficient.

f. Providing effective language models and input.

g. Training teachers

h. They are visually appealing.

Richards in Damanik (2019) revealed some disadvantages of using a textbook, they are:

a. Containing inauthentic language

b. They may distort content.

c. They may not reflect students' needs.

d. They can deskill teachers.

e. They are expensive.

However, aside from the positive and negative impacts of using a textbooks, it is believed that the the English textbook is needed and helpss the learners in English as a Foreign Language classrooms. If the textbook, which is used in the learning program, has some negative effects, the remedial actions need to be taken by adjusting or supplementing books or by giving suitable direction and assistance of using them appropriately (Richards, 2001). Similar to the idea above, Ur in Pratiwi (2014) stated that it is substantial to check the existence of the exercises in the textbook because one of the characteristics of a good textbook is it is able to provide the learner with varied tasks and exercises which encourage the students to have high order thinking skills.

Furthermore, Linse in Pratiwi (2014) stated that reading involves the higher-order thinking skills. It is much more complex than merely decoding specific words. Teaching the students to obtain meaning as well as analyze and synthesize what the learners have read is an important component of the reading process. Therefore, teaching and training students to have higher-order thinking skills is important for students' improvement in reading skills.

Novary (2015: 9) stated that reading comprehension is the ability to process information that we have read and to understand its meaning. Comprehension is a complex process; it needs multiple cognitive skills and stored memory, therefore some problems in improving comprehension must be overcome. First, we need to be able to identify weaknesses in specific cognitive skills. Finally, we have to be able to identify that several elements of comprehension like vocabulary as well as prior knowledge are difficult to target elements to acquire in training and intervention.

Ehri in Yousefi \& Mohammadi, (2016) mentioned that reading comprehension is considered to be a cognitive process. It is one of the ways to establish students' critical thinking. Furthermore, Yousefi \& Mohammadi (2016) mentioned that there was a significant relationship between critical thinking and reading comprehension. Comprehension is a thinking process that not only depends on the comprehension skills but also the experience and background knowledge of the readers. It means that comprehension is accomplished when a reader successfully filters useful knowledge from a text and constructs it into a new understanding of their own.

To have a critical thinking skills students need to think critically and logically based on their knowledge. By using critical thinking, students have the ability to analyze the text without checking a dictionary when they get any difficult words. So, the interrelation between critical thinking and reading comprehension is the higher the students' critical thinking, the higher the students get reading comprehension ability. Therefore, students need to answer the reading questions at all levels of thinking. Following is the type of reading comprehension question suggested to find in teaching and learning, as well as in the textbooks used in the teaching and learning process.

\section{Type of Questions}

Bloom (1956) has helped us with his taxonomy to construct and analyse questions on different levels of thinking. This taxonomy scopes from lower to higher levels of cognitive thinking. Bloom's taxonomy was revised by 
Anderson \& Krathwohl (2001). This taxonomy divides the way people learn and think into two domains, lower-order thinking skills (LOTS) and higher-order thinking skills (HOTS). These domains are further divided into categories or levels. They are remembering, understanding, applying, analyzing, evaluating, and creating.

\section{a. Remembering Category}

The keywords used are who, what, why, when, omit, where, which, choose, find, how, define, label, show, spell, list, match, name, relate, tell, recall, select.

\section{b. Understanding Category}

The keywords used is compare, contrast, demonstrate, interpret, explain, extend, illustrate, infer, outline, relate, rephrase, translate, summarize, show, classify

\section{c. Applying Category}

The keywords used is apply, build, choose, construct, develop, interview, make use of, organize, experiment with, plan, select, solve, utilize, model, identify.

\section{d. Analyzing Category}

The keywords used is analyze, categorize, classify, compare, contrast, discover, dissect, divide, examine, inspect, simplify, survey, take part in, test for, distinguish, list, distinction, theme, relationships, function, motive, inference, assumption, conclusion.

\section{e. Evaluating Category}

The keywords used is award, choose, conclude, criticize, decide, defend, determine, dispute, evaluate, judge, justify, measure, compare, mark, rate, recommend, rule on, select, agree, interpret, explain, appraise, prioritize, opinion, support, importance, criteria, prove, disprove, assess, influence, perceive, value, estimate, influence, deduct.

\section{f. Creating Category}

The keywords used is build, choose, combine, compile, compose, construct, create, design, develop, estimate, formulate, imagine, invent, make up, originate, plan, predict, propose, solve, solution, suppose, discuss, modify, change, original, improve, adapt, minimize, maximize, delete, theorize, elaborate, test, improve, happen, change.

\section{METHOD AND PROCEDURE}

The data of this research were reading comprehension questions found in all English textbooks. There were ten English textbooks used in the EFL classroom in SMAN Kota Padang. Each textbook was used for two semesters. All of those textbooks were analysed using Bloom Category revised by Anderson \& Krathwohl (2001).

In this study, the writer collected and listed all questions of the reading tasks that come after every reading text. The writer divided all the reading exercises based on the chapter in the textbook. Then, the writer classified the questions based on the higher-order thinking skill (HOTS) and Low Order Thinking Skills (LOTS) using Bloom's taxonomy which was revised by Anderson \& Krathwohl (2001), and each of the questions analyzed was classified into the characteristics of HOTS and LOTS categories.
The writer used the checklist table and the indicator form to analyze and compare the distribution of the higher-order thinking skill in the reading exercises of English textbook grade X, XI, XII. Then, the writer counted the total of every cognitive skill from the reading questions and compared it to every level to discover the amount of the distribution of the -higher-order and the lower-order thinking skills in the reading task of the textbooks.

After calculating and classifying the questions based on HOTS categories, the writer also listed the reading questions which only belong to the higher-order thinking skills and divided them based on each category in the higher-order thinking level, whether it is analyze, evaluation, and create to find out what type of the higherorder thinking questions found in the textbooks. The writer also calculatedthe distribution of the low order thinking level based on the revised edition of Bloom's taxonomy. Finally, the writer presents the example of high order thinking skills questions found in the textbooks investigated in this research.

\section{RESULTS AND DISCUSSION}

After analyzing ten English textbooks, 1841 questions involving all categories were found at every level of the cognitive domain. There are 425 HOTS questions including analyzing, evaluating, and creating and 1416 LOTS questions. See Table 1.

Table 1.Total numbers of reading comprehension questions

\begin{tabular}{|c|c|c|}
\hline No & Categories & $\begin{array}{c}\text { HOTS and } \\
\text { LOTS }\end{array}$ \\
\hline 1. & $\begin{array}{l}\text { Remembering-recognizing or recalling } \\
\text { knowledge from memory. Remembering is } \\
\text { when memory is used to produce or retrieve } \\
\text { definitions, facts, or lists, or to recite } \\
\text { previously learned information. }\end{array}$ & \multirow{3}{*}{$\begin{array}{c}1416 \\
(76.91 \%) \\
\text { HOTS }\end{array}$} \\
\hline 2. & $\begin{array}{l}\text { Understanding-constructing meaning } \\
\text { from different types of functions be they } \\
\text { written or graphic messages or activities like } \\
\text { interpreting, exemplifying, classifying, } \\
\text { summarizing, inferring, comparing, or } \\
\text { explaining. }\end{array}$ & \\
\hline 3. & $\begin{array}{l}\text { Applying - carrying out or using a } \\
\text { procedure through executing, or } \\
\text { implementing. Applying relates to or refers } \\
\text { to situations where learned material is used } \\
\text { through products like models, presentations, } \\
\text { interviews or simulations. }\end{array}$ & \\
\hline $4 .$. & $\begin{array}{l}\text { Analyzing---Breaking materials or concepts } \\
\text { into parts, determining how the parts relate to } \\
\text { one another or how they interrelate, or how } \\
\text { the parts relate to an overall structure or } \\
\text { purpose. }\end{array}$ & \multirow{3}{*}{$\begin{array}{c}425 \\
(23.09 \%) \\
\text { LOTS }\end{array}$} \\
\hline 5. & $\begin{array}{l}\text { Evaluating---Make judgments based on } \\
\text { criteria and standards through checking and } \\
\text { critiquing. }\end{array}$ & \\
\hline 6. & $\begin{array}{l}\text { Creating---Compiling the information } \\
\text { together in a different way by combining } \\
\text { elements in a new pattern or proposing } \\
\text { alternative solutions. }\end{array}$ & \\
\hline
\end{tabular}


The following is the number of LOTS questions found in the reading comprehension question of English textbooks:

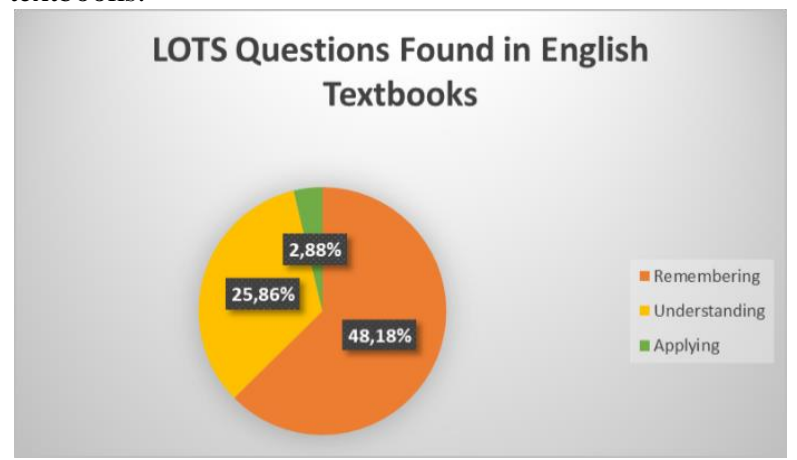

Figure 1: The numbers of LOTS Questions Found in English Textbooks

It was also found that there were 425 questions involving HOTS questions as in the following table

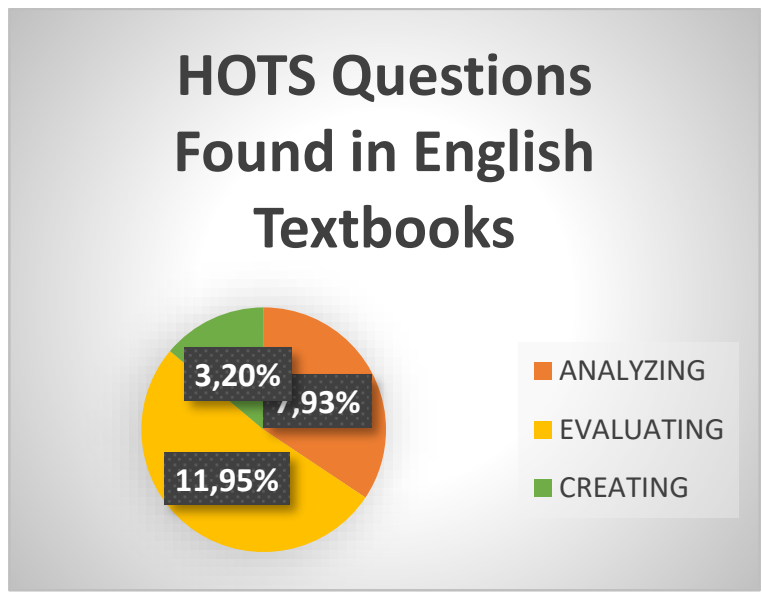

Figure 2: The Total of HOTS Questions Found in English Textbooks

The reading comprehension questions found in the English textbooks in the EFL classroom in SMAN Kota Padang were already using the HOTS categories in the questions. However, the number of LOTS questions outraged the number of HOTS questions. Only 146 questions $(7.93 \%)$ for analyzing category, 220 questions included in the evaluating category $(11.95 \%)$, and 59 questions $(3.20 \%)$ were included in the creating category. The HOTS questions found in the reading comprehension questions of English textbooks have almost reached the proportion but still under the criteria of good proportion. This research results revealed the same as that of Damanik (2019). She found that the English textbook which is included in her research still under the criteria of good proportion and needs improvement in terms of HOTS questions. Therefore, teachers in this research are encouraged to use other sources to provide students with HOTS questions.

Awad (2013), Freahat \& Smadi (2014), Gökhan (2016) also found that there were some problems with textbooks. Their research revealed that some of the textbooks may not cover the higher levels of reading comprehension questions, and they focused more on reading questions in the lower level, thus ignoring the higher level of reading questions.

The following are examples of each category of HOTS questions found in the English textbooks used in EFL classroom at SMAN Kota Padang.

\section{a. Analyzing}

Analyzing is examining and breaking information into parts by identifying motives or causes; making inferences and finding evidence to support generalizations. Here are the questions of analyzing category:

1. How is the park different from the parks in cities? This question refers to the analyzing category because this question is about the differences between the composition of parts. It tells about how the park is different from other parks in cities.

2. Can you find any similarities between Ki Hajar Dewantara and yourself? Describe.

This question refers to the analyzing category because this question distinguishes between the component of parts. It distinguishes the students' personality/appearance with the $\mathrm{Ki}$ Hajar Dewantara.

\section{Evaluating}

Evaluating is presenting and defending opinions by making judgments about information, validity of ideas or quality of work based on a set of criteria. Here are the questions of evaluating category:

1. What do think about the Indonesian military power compared to that of the British army at that time?

The question refers to the evaluating category because this question is about the students' opinion of the Indonesian military compared to that of the British army. Opinion and compare are the words from the characteristics of the evaluating category.

2. Do you think it is important to have faith? Why? Give reasons to support your answer.

The question refers to the evaluating category because it asks the students' opinions about the importance of having faith. Opinion and importance are the words from the characteristic in evaluating category.

\section{Creating}

Creating is compiling information together in a different way by combining elements in a new pattern or proposing alternative solutions. Here are the questions of creating category:

1. If you were in the story, which role would you play? Why?

This question refers to the creating category because this question asking about the choosing role that would you play. In creating category also compiling information together in a different way by combining 
elements in a new pattern or proposing alternative solutions. In addition, the word choice in this question is one of the words used in the creating category.

2. If you had a chance to rewrite the story, how would the story end? Write a new ending of the story.

This question refers to the creating category because the students are asked to rewrite the ending of the story. It means that the students imagine the new ending in a new pattern or a different way. In addition, the word imagine is one of the words used in the creating category.

\section{CONCLUSIONS}

This research focused on the analysis of reading comprehension questions found in English textbookss at SMAN Kota Padang. The purposes were to identify the level of reading comprehension questions in English textbooks based on the HOTS category. The data were coming from the reading comprehension questions in English textbookss at grade X, XI, and XII used in SMA Negeri Kota Padang. It was found that there were 1841 LOTS and HOTS reading comprehension questions from ten textbooks. However, the number of LOTS questions far more than the HOTS questions.

It is concluded that the number of reading comprehension questions in English textbookss should have more HOTS questions in order to improve the students' critical thinking. Therefore, teachers are suggested to provide students with other materials besides the textbooks involved in this research.

\section{ACKNOWLEDGMENTS}

A sincere gratitude is expressed to Lembaga Penelitian dan Pengabdian Masyarakat, Universitas Negeri Padang, for sponsoring the research. Special thanks are also delivered to all parties who have contributed.

\section{REFERENCES}

[1] Anderson, L. W., \& Krathwohl, D. R. (2001). A Taxonomy for Learning, Teaching and Assessing A Revision of Bloom's Taxonomy of Educational Objectives Complete Edition. New York: Longman.

[2] Awad, A. (2013). Evaluating English for Palestine 12 in Terms of the EFL/ ESL Textbook Evaluating Checklist from the Teachers' Perspectives in Nablus Directorate Schools. An-Najah Univ. J. Res. (Humanities). 27(11), 2013.

[3] Bloom, B. S. (1956). Taxonomy of educational objectives: the classification of educational goals. London.

[4] Damanik, S.N.H. (2019). The Analysis of reading comprehension questions in English textbook using
HOTS categories at grade X of SMAN 2 Padang. Thesis S1: Universitas Negeri Padang.

[5] Febrina, F., Usman, B., \& Muslem, A. (2019). Analysis of Reading Comprehension Questions by Using Revised Bloom's Taxonomy on Higher Order Thinking Skills (HOTS). ENGLISH EDUCATION JOURNAL (EEJ), 10(1), 1-15, January.

[6] Freahat, N. M., \& Smadi, O. M. (2014). Lowerorder and higher-order reading questions in secondary and university level EFL textbooks in Jordan. Theory and Practice in Language Studies, 4(9), 1804-1813.

[7] Gökhan, O. (2016). A Descriptive Content Analysis of the Extent of Bloom's Taxonomy in the Reading Comprehension Questions of the Course Book Q: Skills for Success 4 Reading and Writing. University of Hakkari, Turkey. The Qualitative Report, 21(9), 1674-1683.

[8] Graves, K. (2000). Designing Language Courses: A Guide for Teachers. Boston: Thomson Heinle \& Heinle.

[9] Pratiwi, N. (2014). An Analysis of Reading Exercises in Pathway to English Textbook for the Eleventh Grade of Senior High School Students. Jakarta: UIN

[10] Yusoff, W. \& Selman, S. (2018). Teachers Knowledge of Higher Order Thinking and Questioning Skills: A Case Study at a Primary School in Terengganu, Malaysia. International Journal of Academic Research in Progressive Education \& Development. Retrieved from http://dx.doi.org/10.6007/IJARPED/v7-i2/4120

[11] Damanik, S.N.H \& Zainil, Y. (2019). The Analysis of Reading Comprehension Questions in English Textbook by Using Higher Order Thinking Skills at Grade X of SMAN 2 Padang. Journal of English Language Teaching Volume 8 No. 1. 